\title{
RIGLYNE VIR VOORTGESETTE TEOLOGIESE OPLEIDING: UITDAGINGS VIR DIE AGS-KERK
}

Author:

Andries Putter ${ }^{1}$

\section{Affiliation:}

${ }^{1}$ Departement

Praktiese Teologie,

Noordwes-Universiteit

Potchefstroomkampus,

Suid-Afrika

\section{Correspondence to:}

Andries Putter

email:

andriesputter@telkomsa.net

Postal address:

Posbus 17584, Pretoria-

Noord 0116, Suid-Afrika

\section{Keywords:}

riglyne; voortgesette teologiese opleiding; AGSpastors; rolverwagtinge

\section{Dates:}

Received: 13 Julie 2010

Accepted: 03 Sept. 2010

Published: 18 Nov. 2010

How to cite this article: Putter, A., 2010, 'Riglyne vir voortgesette teologiese opleiding: Uitdagings vir die AGS-kerk', Verbum et Ecclesia 31(1), Art. \#417, 8 pages. DOI: 10.4102/ ve.v31i1.417

\section{This article is available} at:

http://www.ve.org.za
(C) 2010. The Authors. Licensee: OpenJournals Publishing. This work is licensed under the

Creative Commons

Attribution License.

\section{ABSTRACT}

Guidelines for continuous theological training: Challenges for the Apostolic Faith Mission church Qualitative research done amongst a section of the broader membership as well as a region of the Apostolic Faith Mission (AFM) church has identified the role expectations of the pastor. Studies have shown that pastors should be continuously equipped to enable them to meet all their role expectations successfully. Although successful pastorates are a priority for the AFM, no formal structures have been constituted to guide pastors to become involved in continuous theological training. A literature research was also undertaken in order to obtain a larger and representative picture of the continuous training of pastors. The research and literature study findings have led to the drafting of proposed guidelines for continuous theological training. The purpose of this article is to provide these guidelines to the AFM church role players for them to remain informed regarding continuous theological training. This will enable pastors to stimulate congregational growth and address different training needs.

\section{INLEIDING}

By die Apostoliese Geloof Sending van Suid-Afrika (AGS) se Algemene Besigheid Vergadering in Mei 2008 is grondwetlike wysigings goedgekeur wat vir net een instelling van teologiese opleiding in dié kerk voorsiening maak (Burger \& Nel 2008:402-403). Die gevolg van hierdie besluit was dat die AGS se leiers krities moes nadink oor die belangrike rol wat teologiese opleiding in die toekoms kan speel. Dus word daar deurlopend krities oor die inhoud en relevansie van teologiese opleiding besin.

Uit die geskiedenis van teologiese opleiding in die AGS, het Putter (2006:16-80) redes uitgewys waarom pastors nog nie by voortgesette opleiding betrokke geraak het nie. Tog het deelnemers aan Putter (2006, 2009) se navorsing oor die rolverwagtinge van AGS-pastors aangedui dat hulle voortgesette opleiding as noodsaaklik beskou. Voorts het navorsing getoon dat, hoewel 'n doeltreffende pastor ' $\mathrm{n}$ prioriteit is, daar nogtans nie gevestigde strukture bestaan om pastors te begelei om by voortgesette teologiese opleiding betrokke te raak nie. Uit sowel 'n kwalitatiewe ondersoek as 'n literatuurstudie van Putter blyk duidelik hoe belangrik voortgesette teologiese opleiding vir die AGS-pastor geword het. Die rolverwagtinge wat van pastors gekoester word, soos uit die navorsing blyk, bied 'n aanduiding van die verwagte inhoud en aard van sodanige opleiding. Hierdie artikel poog om riglyne te bied vir die groter AGS-kerk om die pastor by voortgesette teologiese opleiding betrokke te kry.

Vervolgens word die geskiedenis van teologiese opleiding in die AGS vlugtig dog krities bespreek.

\section{GESKIEDENIS VAN TEOLOGIESE OPLEIDING IN DIE AGS}

Die geskiedenis van teologiese opleiding in die AGS (Putter 2006:1-80) wys op die moontlike redes waarom teologiese opleiding genegeer is.

\section{Botsende beskouings van die AGS-kerk en die samelewing}

Vroeër was teologiese opleiding nie 'n voorvereiste vir die bediening in die AGS nie. Om tot die bediening toegelaat te word, moes 'n voornemende kandidaat 'geroepe' wees en om toelating aansoek doen. 'n Persoon se bediening is bevestig deur die uitreik van 'n sertifikaat deur die Uitvoerende Raad (Van der Spuy 1985:105-106; AGS van SA 1909:24, 35). Die noodsaaklikheid van Bybel opleiding ('n ander naam vir teologiese opleiding) is uitgewys, maar dit was duidelik dat die klem (volgens die AGS se destydse standpunt) eerder op Bybelkennis moes val, en nie soseer op teologiese opleiding soos in ander kerke nie (Erasmus 1996:13). Hierdie gesindheid het lede van die AGS verhewe bo ander kerke laat voel. God se vermoë om te genees, wonderwerke te doen, en die doop van die Heilige Gees by wyse van spreke in ander tale te ervaar, is as belangrik beskou; die houding was een van teenkanting teen teologiese opleiding (Van der Spuy 1985:107). Volgens Eybers, König en Stoop (1978:174) het Pinkstermense in die ontstaansjare van die AGS nooit veel belangstelling in akademies-teologiese besinning getoon nie. Die ingesteldheid jeens die akademiese ontwikkeling van die pastor, en ook die aanspreekvorm 'pastoor', het eers ná bykans vyf dekades in die AGS ontwikkel (AGS van SA 1957: boek 19, 4919; Burger 1987:306).

As gevolg van gebrekkige teologiese opleiding van pastors was die samelewing bevooroordeeld. Pastors en lede kon onder andere nie in skoolrade en ander gemeenskapsrade dien nie, en die gebrek aan teologiese opleiding het ook dikwels verhinder dat pastors as huweliksbevestigers en vir uitsaaigeleenthede by die SAUK gebruik is (Burger 1987:239-242).

\section{Moeilike ekonomiese toestande in Suid-Afrika}

Finansies het'n groot rol gespeel in die gereelde sluiting van opleidingsinstansies in die AGS. Dié kerk was op die punt van bankrotskap as gevolg van die skuld wat die uitvoerende gesag van die AGS 
in 1929 aangegaan het om die hoofkantoor te vergroot (Burger 1987:264-267). Vele lidmate van die AGS het uit die kerk bedank uit vrees dat die AGS, as 'n openbare instansie, hul persoonlike finansies sou beïnvloed. Die invloed van die depressie en die finansiële krisis waarin die kerk hom bevind het, het daartoe bygedra dat gemeentes se inkomstes gedaal het en dat die voltydse werkers van die kerk nie maandeliks betaal kon word nie. Die gevolglike finansiële krisis waarin die kerk hom bevind het, het ook die pastor se teologiese ontwikkeling laat skade ly (AGS van SA 1932:1285)

\section{Politieke situasie in die land}

Jare se teologiese opleiding, veral van Swart studente, is deur die staat se groepsgebiedewette benadeel, deurdat die plek van opleiding gedurig verskuif of gesluit is (AGS van SA 1964a:108; AGS van SA 1964b:109). Toelatingsvereistes het gewissel na gelang van ras en agtergrond. Die Swart afdeling van die AGS het besliste hindernisse ten opsigte van akademiese ontwikkeling beleef (Erasmus 1996:12)

Dieselfde verskynsel is ook in die onderwys waargeneem deurdat die Wet op Swart Onderwys, Wet 47 van 1953, Swart onderwys onder die beheer van die sentrale owerheid geplaas het (Zwemstra 2007:144). Swart skole in Blanke gebiede is gesluit, en sendingorganisasies se beheer oor Swart skole is weggeneem (Terreblanche 2002:334). In die tydperk 1948-1994 het die regering ook tien keer meer geld aan Blanke opleiding as aan Swart bemagtiging bestee (Thompson 1990:196-197).

\section{Afstandsonderrig is afgeskeep}

Die vierde Bybelkollege van die AGS, wat in 1950 deur dr F.P. Möller op die been gebring is, was aanvanklik 'n korrespondensiekollege (AGS van SA 1950:3524). Die studentetal het vinnig toegeneem, en teen die jaar 1956, toe die kollege 'n binnemuurse departement begin het, was daar reeds 325 studente wat vir die korrespondensiekursus ingeskryf het (AGS van SA 1950:3524)

Met die oorname van pastor Cronjé as hoof in 1969, is daar ongelukkig meer op binnemuurse opleiding gekonsentreer, en is afstandsonderrig as opleidingsmetode afgeskeep (Erasmus 1996:112). In 1976 het Cronjé verklaar dat die hooffunksie van die kollege die aanbieding van binnemuurse studie is. Hy het nie eens afstandsonderrig as alternatiewe opleidingsmetode genoem nie (Cronjé 1976:38)

Die kollege se komitee was veral in die sewentigerjare van mening dat binnemuurse studie beter opleiding as korrespondensiestudie bied (AGS van SA 1970:1). Die Blanke Uitvoerende Raad van die AGS het dan ook in 1969 'n ouderdomsperk vir die korrespondensiekursus ingestel. Slegs persone bo 35 kon inskryf. Diegene onder 35 moes die binnemuurse kursus volg (AGS van SA 1969:7563). Hierdie besluit het ongelukkig veroorsaak dat die groter geleenthede wat korrespondensie-opleiding vir die student sowel as die teologiese instansie kon bied, nie benut is nie. Die grootste waarde van korrespondensie-opleiding lê immers daarin dat dit enersyds studie binne die bereik van meer studente plaas en die plaaslike gemeentes as vennote betrek, en andersyds die teologiese instansie sigbaarder maak en groter finansiële steun fasiliteer.

\section{Weerstand teen formele opleiding}

AGS-leiers se weerstand teen formele opleiding was onder andere die gevolg van 'n teenreaksie op die opgeleide predikante van die tradisionele Afrikaanse susterskerke. Enersyds was daar die gevoel dat die predikante, ten spyte van hul geleerdheid, nie daarin geslaag het om hul mense tot 'n ontmoeting met God te lei nie. Andersyds het die 'geleerde' predikante se soms krasse en liefdelose veroordeling van AGS-leiers hierdie weerstand laat toeneem (Van der Spuy 1985:106). In teenstelling daarmee was dit dikwels die ongeletterde 'lekewerkers' in die AGS wat die Woord eenvoudig dog kragdadig verkondig het, en is die verkondiging van die Woord met wonders en tekens bevestig. Skrifgedeeltes soos 1 Korintiërs 2:1-6 (dat die apostel nie in die wysheid van die mens nie, maar in die krag van God en die eenvoud van Christus opgetree het) en 2 Korintiërs 3:6 (dat die letter doodmaak en die Gees lewend maak) is dikwels gebruik om die weerstand teen kennis te regverdig. Die gedagte is dus ingeprent - en dit is jammer dat daar dikwels uit die oog verloor word - dat die wonders deur God gedoen is 'ongeag' ongeleerdheid, en nie 'vanweë' ongeleerdheid nie.

Weerstand teen formele opleiding het in die AGS-kerk voortgeduur (Burger \& Nel 2008:401). Die hoof van die Blanke kollege, pastor F.H.J. Cronjé (1979:46), het aangevoer dat die akademiese standaard van die AGS Teologiese Kollege (AGSTK) in die tydperk 1970-1995 goed met dié van BD-studente aan 'n universiteit vergelyk het. Hy beklemtoon egter die salwing van die Heilige Gees, wat beteken dat geestelikheid vir die kollege bo die wetenskaplike kennis verhewe is. Hy meen dat die BD-kursus net by eksegese meer werk vereis, waarin die Pinksterman nie so baie oefening nodig het nie. Hy skryf: 'Die Heilige Gees is tog die grootste openbaarder van waarheid, waarvan die toepassing van wetenskaplike kennis in dié verband maar slegs inleidend van aard is' (Cronjé 1979:46). Dit is duidelik dat Cronjé nog met 'n tweeledige denkwyse geworstel het, wat 'n voortsetting was van die ou spanning tussen die werking van die Heilige Gees en wetenskaplike akademiese opleiding. Hierdie ingesteldheid by Cronjé het heel waarskynlik daartoe gelei dat oorspronklike of grondtale sowel as eksegetiese studie van die Bybel as inleidend en van mindere belang beskou is. Erasmus (1996:112) is van mening dat die opvatting geheers het dat openbaringskennis, via die leiding van die Heilige Gees, sonder wetenskaplike Bybelse eksegese bekom kon word. Die geloof in die Heilige Gees het die gedagte laat ontstaan dat die oorspronklike verklaring van die Skrif moontlik is sonder die wetenskaplike studie van die Bybel. Die gevolg was dat die studie van kritiese vraagstukke, die oorspronklike tale, hermeneutiek en teologie as minder belangrik beskou is. Aan die ander kant sou Sistematiese Teologie en Praktiese Teologie weer beklemtoon word, omdat dit as die verklaring en toepassing van die openbaringskennis beskou is (Erasmus 1996:112).

\section{Onvoldoende opleiding}

Putter (2006:1) meld dat pastors jaarliks enkele pastorsbidure in geografiese streeksverband bywoon, waar inligting oor gemeentebediening verskaf word. Volgens Putter kan dít nie die AGS-pastor voldoende toerus nie. Die verskillende opleidingsmodelle wat AGS-pastors vir toelating tot die bediening bekwaam het, het van 'n jaar lange (nie-geordende) sertifikaatprogram tot 'n honneursgraad in Teologie gewissel. Die verskillende opleidingsmodelle, standaarde en kulturele agtergronde het eenheid en samewerking tussen die onderskeie kolleges ten opsigte van (voortgesette) teologiese opleiding bemoeilik. Die nuwe enkele instelling vir teologiese opleiding in die AGS met ingang van 2009 staan voor groot nuwe uitdagings ten einde die verskillende standaarde en kulturele agtergronde te laat saamwerk.

Die onbekendheid van formele tersiêre opleiding, en onkunde oor nuwe studierigtings, het veroorsaak dat pastors huiwerig is om by voortgesette teologiese opleiding betrokke te raak. 'n Gebrek aan tyd en geld word voorts as redes aangevoer waarom pastors nog nie voortgesette opleiding oorweeg het nie.

\section{Onrealistiese rolverwagtinge}

Eerstens het die AGS-pastor mettertyd die gebruik aanvaar om jaarliks 'n sensusvorm te voltooi, waarop die getallegroei of -afname aangedui word. Die sukses van 'n pastor se werk is aan die hand van die gemeentegroei bepaal. Sou die sensusopname 
negatiewe groei toon, is die pastor daarvoor verantwoordelik gehou.

Tweedens is die algehele herderlike versorging van die gemeente as die taak van die pastor beskou. Van den Berg (1991:66) noem dat daar teen 1960 al 'n tydvak bereik is waar die pastoraat alleen verantwoordelik was vir die bediening in die gemeente, en dat die lekewerkers (ouderlinge en diakens) feitlik onaktief was. In ons tyd word die pastor as die sleutel tot 'n florerende gemeente beskou. Dit beteken vanselfsprekend dat die pastor se verpligtinge ál meer geword het, en dat daar al hoe minder tyd en geleentheid vir persoonlike opleiding was en is.

Aangesien die AGS-pastor die spil bly waarom die bediening van 'n gemeente draai, en hy tegelykertyd herder, leraar, evangelis, sieketrooster, administrateur, organiseerder, instandhouer, pastorale konsultant en algemene voorligter is, het uitbranding by pastors 'n ál groter probleem geword (Erasmus 1990:125-126).

Grobbelaar $(2007: 4,5,86)$ het in haar navorsing getoon dat die geweldige stres wat predikante van die Gereformeerde Kerke van Suid-Afrika (GKSA) beleef, aan die hoë verwagtinge toegeskryf kan word wat gemeentelede van hul predikante koester. Volgens Grobbelaar $(2007: 5,174)$ verwag lidmate dat predikante hul geestelike nood sal ken en beskikbaar sal wees vir hul geestelike opbouing.

\section{Samevatting}

Die geskiedenis van teologiese opleiding in die AGS toon dus duidelik waarom teologiese opleiding genegeer is en pastors nog nie geredelik vir voortgesette teologiese opleiding inskryf nie.

Vervolgens word Putter (2006:81-146; 2009:1-7) se navorsingsresultate bondig bespreek ten einde aan die groter AGS-kerk te bewys waarom voortgesette opleiding vir pastors 'n noodsaaklikheid geword het.

\section{NAVORSINGSRESULTATE}

In Putter se 2006-navorsing het die AGS-hoofkantoor 'n groep AGS-lidmate gekies om as verteenwoordigers van die groter AGS aan 'n projek deel te neem (Putter 2006:8-12). Deelnemers het gewissel van getroudes, tieners en senior burgers, tot leiers, nie-aktiewe lidmate sowel as voltydse pastors. Met die hulp van die AGS-hoofkantoor, is werksessies oor die hele land gehou. Dié werksessies was verteenwoordigend van al die gemeentes, ongeag verskille in kultuur, taal en ekonomiese omstandighede, en het sowel plattelandse as stedelike AGS-gemeentes ingesluit ten einde die betroubaarheid van die ondersoek te verhoog (kyk Holliday 2002:41).

In Putter se 2009-navorsing (2009:1-7) het die leierskap van die Ophir Netwerk (die destydse Suidoos-Gauteng-streek van die AGS) hul pastors en eggenote gekies om aan die projek deel te neem. 'n Werksessie vir die Ophir Netwerk-pastors het by Alpine Heath in die Drakensberge plaasgevind. Weereens was die deelnemers divers, onder meer jeug en medeleraars, AGSpastors met een tot 15 jaar voltydse bedieningsondervinding, AGS-pastors met 16 tot 25 jaar voltydse ondervinding, en AGSpastors met 26 en meer jaar voltydse ondervinding.

Al die deelnemers aan die 2006- en 2009-ondersoeke is doelbewus gekies om aan die navorsingskriteria te voldoen en die nodige inligting ten opsigte van die pastor se rolverwagtinge te verskaf (kyk Burns \& Grove 1993:58). By al die werksessies is die ses maatstawwe waaraan deelnemers moes voldoen, gehandhaaf. Nadat hulle oor die aard en doel van die ondersoek ingelig is, en verseker is dat alle inligting sowel as hul identiteit as vertroulik beskou sou word (kyk Creswell 1994:147-148), het alle deelnemers hul naam op 'n presensielys aangeteken ten einde skriftelik toestemming te verleen dat die inligting vir navorsing gebruik mag word. Die vraag 'Wat is die rolverwagtinge van die AGS-pastor?' is in sowel die 2006- as die 2009-werksessie gestel. Deelnemers is aangemoedig om alles te noem wat na húl mening deel uitmaak van die pastor se rolverwagtinge, omdat geen inligting verlore moes gaan nie. Voorts is veldaantekeninge deur middel van kernwoorde en -frases gemaak om waarnemings akkuraat op te teken. Die aantekeninge is later breedvoerig aangevul (kyk Knafl \& Breitmayer 1989:434-436). Gedurende die ondersoek kon die navorser niks toevoeg, weglaat, verdraai of verwring nie; sy taak was slegs om die ondersoek te fasiliteer. 'n Objektiewe benadering is so ver moontlik gehandhaaf. Die inligting uit die werksessies is volgens Tesch (kyk Creswell 1994:154) se beskrywende ontledingsmetode verwerk. 'n Kundige op die gebied van sowel die Teologie as kwalitatiewe navorsing is as onafhanklike kodeerder aangestel. Nadat die gesprekke getranskribeer en gekodeer is, het die onafhanklike kodeerder 'n protokol vir die ontleding van die data ontvang. Die fasiliteerder het die data vervolgens onafhanklik gekategoriseer en gekodeer, waarna die fasiliteerder die inligting vanuit 'n teologiese agtergrond met die navorser bespreek en saamgestel het, sodat 'n eksterne kodeerder die betroubaarheid van die resultate kon nagaan (kyk Krefting 1991:217). Hierna het verskeie konsensusgesprekke tussen die navorser en die eksterne kodeerder gevolg, en is die finale en subkategorieë uitgewys. Putter (2006:81-146, 2009:1-7) het onder andere die volgende belangrike elemente uitgewys.

\section{Opleiding in hoofrolle word toenemend belangrik}

Uit die inligting van die deelnemers en die literatuurstudie het geblyk dat pastors onder meer doeltreffende en relevante predikers, kerkleiers, bestuurders, onderwysers, opleiers, beraders, maatskaplike werkers en fasiliteerders moet wees. Hierbenewens moet hulle lidmate deurlopend in 'n verskeidenheid lewensvaardighede oplei, wat strek van die keuse van 'n huweliksmaat en gesinsbeplanning tot finansiële beplanning, wat onteenseglik voortgesette opleiding vir pastors sal vereis. Pastors se rol as leiers in die gemeenskap is deurgaans beklemtoon.

Verder is benadruk dat pastors toenemend kenners moet wees van die belange van die verskillende kulture in die gemeenskap, en hoe dit tot die bevordering van die koninkryk van God aangewend kan word (Easum 2001:1-47; Kimbal 2003:91-133; Sweet 1999:43-144).

In die lig van die toenemende eise wat aan die voortgesette opleiding van pastors gestel word, word dit dus al hoe belangriker dat alle teologiese seminariums en universiteite in Suid-Afrika sal insien dat hul aandeel aan hierdie voortgesette opleiding van wesenlike belang is. Pastors word immers hiér voorberei om gelowiges toe te rus om die sendingsopdrag van die kerk uit te voer (Hendriks 2004:128). Dít is immers hoe die koninkryk van God uitbrei.

\section{Belang van interpersoonlike vaardighede}

Die aanleer van interpersoonlike vaardighede bevorder soveel fasette van die pastoraat dat dit 'n vereiste vir voortgesette teologiese opleiding is. Die nuwe teologiese instelling van die AGS kan 'n besondere bydrae lewer om pastors se interpersoonlike vaardighede deur middel van voortgesette opleiding met spangesprekke en mentorskap te verbeter, sodat hulle nie stagneer en onnodig aan hul aangeleerde, verouderde denkpatrone vasklou nie.

\section{Voortgesette holistiese opleiding}

Dit is duidelik dat teologiese seminariums en universiteite pastors moet begelei en hul verder moet help vorm, sodat hulle so kan ontwikkel dat hulle aan hul verskillende rolverwagtinge kan voldoen. Teologiese opleiding - hoe algemeen of hoe 
toegespits mens dit ook al wil beskou - is immers veel meer as net die oordrag van teologiese kennis en insig. Dit behels ook vorming.

Die belang van 'n evaluasiestelsel vir teologiese seminariums om te moniteer hoe doeltreffend studente of pastors aan die rolverwagtinge voldoen, sowel as hul volgehoue geestelike, fisieke, intellektuele en emosionele sorg, koestering en ontwikkeling, het duidelik in die navorsing na vore gekom. Nel (2005:460) glo ook dat pastors 'voortgesette teologiese opleiding as 'n kritiese noodsaaklikheid behoort te benader'. Nel (2005) meld voorts: 'Every trained pastor needs to stay competent', en bied die volgende as redes vir dié stelling aan:

- The increasing and continuing changes in society.

- The fact that theological training does not end with formal training in faculties of theology.

- The fact that it is not only theological professors who train people for public pastoral leadership.

(Nel 2005:460)

Die Evangeliese Lutherse Kerk in Amerika (1995) motiveer die behoefte aan voortgesette opleiding vir hul pastors soos volg:

Because of the changing, diverse context of our mission, it is necessary that leaders continually grow in grown faith, expand their skills and increase knowledge through continuing education ... While it is expected for all pastors ... it is certainly needed in the early, formative years of ministry in specific contexts ... The church must encourage and provide resources for its leaders to continually develop and renew their gifts for ministry through disciplined patterns of life-long learning.

(Evangelical Lutheran Church in America 1995:29)

\section{Samevatting}

Uit Putter se onderskeie navorsingsondersoeke het derhalwe duidelik geblyk dat lidmate pastors gedurig uitdaag om vir voortgesette teologiese opleiding in te skryf. Vele AGS-pastors wat reeds by voortgesette teologiese opleiding betrokke geraak het, het ervaar dat verskeie universiteite se dosente veel meer as net goeie begeleiding en ondersteuning bied. Kriteria vir voortgesette teologiese opleiding van die AGS-pastor sal vervolgens bespreek word.

\section{KRITERIA VIR VOORTGESETTE TEOLOGIESE OPLEIDING}

By die oorweging van riglyne vir voortgesette teologiese opleiding moet die volgende sake aandag geniet:

- bewusmaking van die voordele wat voortgesette teologiese opleiding vir die pastor en die groter AGS-kerk inhou

- $\quad$ voorstelle vir voortgesette teologiese opleiding

- die skep van 'n nuwe kultuur in die AGS.

\section{Bewusmaking van die voordele wat voortgesette opleiding vir die pastor en die groter AGS-kerk inhou}

Die outeur reken dat voortgesette opleiding veel meer voordele vir die AGS-pastor en die groter kerk inhou as wat hier onder die loep geneem kan word. Daagliks ervaar pastors wat by voortgesette opleiding betrokke is, dat hulle opnuut persoonlik verryk en vervul word, wat enorme moontlikhede vir die bevordering van die koninkrykswerk van God inhou (Maré 2005:432-446; Putter 2006:188-192; Olwagen 2003:1-9).

Die AGS-hoofkantoor, teologiese instellings, streekrade, plaaslike gemeentes en pastors moet bewus gemaak word van die volgende riglyne en voordele wat, volgens die navorsingsbevindinge, voortgesette teologiese opleiding sal bevorder.
Opleiding in die verskeie rolverwagtinge van die pastor Voortgesette teologiese opleiding kan 'n besondere bydrae lewer deur die pastor in staat te stel om op al die gebiede waar die rolverwagtinge van die pastor dit vereis, deurlopend te ontwikkel en te vorder.

Eerstens kan die teologiese grondslag wat hul basiese opleiding in die verlede gelê het, verder uitgebou word. Pastors se kennis van die Bybel; hul persoonlike sterk punte; aspekte waarin hul opleiding nodig het; hul verhouding met mense in die algemeen, sowel as met die omgewing, gesin, gemeente en self, en ander relevante sake kan verbeter en uitgebou word. Tweedens kan hulle sekere vaardighede by spesialiste aanleer en doeltreffend op alle gebiede (die self, gesin, gemeente en gemeenskap) toepas. Derdens kan voortgesette opleiding pastors vir sekere noodsaaklike bedieningsrolle ontwikkel en toerus, terwyl dit vierdens vir volgehoue geestelike groei sorg.

Bevorder beter voorbereiding ten einde aansoek te doen om beroepe in die kerk sowel as ander verwante beroepe

Navorsing het getoon dat pastors wat oor nagraadse kwalifikasies beskik en met voortgesette opleiding besig is, met groter vertroue om poste in plaaslike gemeentes sowel as in die privaat sektor kon aansoek doen as pastors daarsonder (Van Niekerk 2000:356). Dít was dan ook die geval met die oudstudente van die Stofbergskole, wat tans hoë poste buite die kerk beklee. Van Niekerk stel dit verder dat 'dit tot voordeel van die samelewing is, maar die kerk verloor so baie van sy opgeleide mense vir die voltydse bediening' (Van Niekerk 2000:357). Vandag is dit 'n uitgemaakte saak dat persone wat deurlopend ontwikkel, die beste funksioneer vir die take wat hul onderskeie beroepe van hulle vereis. Gemeentelede kry in die arbeidsmark immers ook erkenning vir hul pogings tot selfopleiding, uitbreiding van hul kennis, en verwerwing van vele vaardighede.

\section{Groter vervulling, werksbevrediging en persoonlike verryking}

Pastors wat by voortgesette opleiding betrokke kon raak getuig almal van die persoonlike vervulling, werksbevrediging en verryking wat hulle daardeur ervaar het. Kursusse wat onder andere praktykgerigte opleiding behels, stimuleer die pastor se intellektuele vermoëns, en bring verder mee dat daar verkwikkende en verfrissende nuwe energie onder pastors vrygestel word. Hierdie energie word persoonlik, in die gesin, gemeente en samelewing tot voordeel van die koninkryk van God se werk aangewend (Putter 2003:37; Olwagen 2003:46). Verder sal formele voortgesette teologiese opleiding by pastors uit die aard van die saak verdere lees, navorsing en persoonlike selfdissipline bevorder.

Om relevant, ingelig en tersaaklik ten opsigte van die hedendaagse mens se behoeftes te funksioneer

'n Rolverwagting wat die navorsingsresultate uitgewys het, is dat pastors deurlopend relevant, ingelig en tersaaklik moet funksioneer. In hierdie verband kan kursusse, wat praktyk- én Bybelgerigte opleiding behels, 'n belangrike bydrae lewer om pastors te help om nuut oor die verstaan en interpretasie van die Bybel te dink en te besin. In aansluiting hierby kan daar ook melding gemaak word van die moontlikheid dat jong pastors wat direk ná skool teologiese opleiding ondergaan het in die vaste oortuiging dat hulle voltyds in die bediening wil funksioneer, probleme kan ondervind om aan hierdie rolverwagting te voldoen. Deurlopende evaluering van hoe hulle aan hul rolverwagtinge voldoen, sal hulle op hul beurt bewus maak van wat hier benadruk moet word, naamlik hoe belangrik en voordelig dit is om relevant, ingelig en tersaaklik te funksioneer.

Aangesien mense vandag uiteenlopend in hul denke, en gekompliseerd en uniek in hul sienswyses is, moet daar met 
groter versigtigheid na hulle geluister word. Nel (2002:159) vra hoeveel noodlottige foute in die teater gemaak moet word alvorens daar besef word dat iemand nie 'n chirurg behoort te wees nie. Hoeveel kinders moet dieselfde vak druip voordat iemand besef: Ek is nie 'n onderwyser nie? Die AGS-kerk se uitvoerende beamptes het ' $\mathrm{n}$ verantwoordelikheid om toe te sien dat AGS-pastors deurlopend as ingeligte en relevante pastors funksioneer. In hierdie verband kan voortgesette opleiding as 'n prioriteit ' $n$ besondere bydrae lewer.

\section{Skep van nuwe mentorskappe, begeleidings en} vriendskappe

Daar is duidelik uitgewys hoe belangrik dit vir die pastor geword het om 'n persoonlike mentor te hê - iemand wat ervare leiding en raad aan pastors kan gee. Senior pastors en dosente kan dikwels as mentors aangestel word om hulp en leiding aan jong pastors te bied. Maré (2003) het uitgewys dat teologiese instellings nie net met mentorskap help nie, maar ook tot die vorming van die pastor se karakter bydra. Verder word die pastor aan die teologiese instellings aan nuwe, motiverende en geestelik verrykende vriendskappe blootgestel.

\section{Bied die geleentheid vir pastors om in spanverband saam te werk en te ontwikkel}

Navorsing het uitgewys dat van die pastors uit die ouer generasie (Silent, Boomers en Gen X) aan vroeër jare se onderrigmetodes gewoond is, waar afsonderlike en individualistiese denkpatrone gevorm is (Codrington 2004:104 -132,196-220). Vrese by pastors as gevolg van die druk en eise omdat hulle deurlopend as individue wil presteer, kan uit die weg geruim word wanneer hulle van voortgesette teologiese onderrig in spanverband bewus gemaak word.

\section{Die blootstelling aan breër teologiese perspektiewe}

Die blootstelling aan voortgesette opleiding dra daartoe by dat die pastor groter insig in teologiese perspektiewe kry, wat hom in staat stel om groter begrip te toon vir wesenlike lewensvraagstukke waarmee mense in ons tyd worstel. Verder dra dit ook daartoe by dat pastors in staat gestel word om krities relevante gesprekke met mense te voer en dit op wetenskaplike, godsdienstige wyse te verwoord. Alle pastors of predikante sal groter erns met hierdie voordeel moet maak, aangesien hulle nie as 'n elitistiese, irrelevante groep voltydse werkers in die kerk bekend mag staan, met 'n eie vaktaal wat slegs deur 'n klein groepie gelowiges verstaan word nie (Joubert 2001:194-195).

Hierdie groter insig stel pastors dan ook aan nuwe en breër denkrigtings bekend, met die gepaardgaande uitbreiding en ontwikkeling van hul leefwêreld. Dít stel hulle in staat om nuut oor teologiese sake te dink. Verder dra hierdie blootstelling aan nuwe teologiese perspektiewe daartoe by dat pastors oor veel meer inligting beskik wat as hulpmiddele gebruik kan word om hul geestelike lewe en vaardighede uit te bou. Hul persoonlike vaardighede ten opsigte van die gesin, gemeente, gemeenskap en groter samelewing word verbeter, sowel as die positiewe insette wat hulle aan kollegas kan lewer.

\section{Voorstelle vir voortgesette opleiding, en die skep van'n nuwe kultuur in die AGS}

Die skep van 'n nuwe kultuur vir voortgesette teologiese opleiding word 'n ál groter uitdaging vir al die verskillende kerke. In gesprekke met predikante word daar gehoor dat 'n nuwe kultuur onder NGK-pastors gevestig moet word alvorens voortgesette opleiding in dié kerk 'n realiteit kan word.

In die AGS-kerk is daar tans na raming 2000 geordende, niegeordende en geaffilieerde pastors in 1800 AGS-gemeentes wat 1.3 miljoen lidmate bedien (AGS van SA 2008:34; De Witt 2010). Aangesien pastors met verskillende tipes opleiding tot die bediening toegelaat kon word (van 'n jaar lange, niegeordende sertifikaat tot 'n honneursgraad in Teologie), sal die skep van 'n nuwe kultuur baie sensitief en versigtig beplan moet word. Teologiese opleiding aan die verskillende teologiese instellings het ook teen verskillende kulturele agtergronde met groot meningsverskille geskied. By die AGS se Algemene Besigheid Vergadering in Mei 2008 is grondwetlike wysigings goedgekeur wat die weg baan vir 'n enkele instelling vir teologiese opleiding in die AGS met ingang van 2009.

Volgens Putter (2006:15-142) blyk duidelik uit die AGS se geskiedenis van teologiese opleiding dat daar van die AGShoofkantoor, teologiese instellings, streekrade, plaaslike gemeentes en pastors verwag word om die pastor toe te rus om aan die onderskeie rolverwagtinge te voldoen. $\mathrm{Al}$ die betrokke persone in die pastoraat moet dus hierdie behoefte as 'n prioriteit beskou.

Die volgende voorstelle word aan die AGS-hoofkantoor, teologiese instellings, streekrade, plaaslike gemeentes en pastors beskikbaar gestel, sodat beter bekendmakings- en toerustingsmetodes 'n realiteit kan word.

\section{AGS-hoofkantoor}

Die ideaal van goeie voortgesette teologiese opleiding moet deur die AGS-kerk se bestuur en alle rolspelers beplan en hanteer word. In die lig van die immer teenwoordige dualisme tussen geestelikheid en die akademie, sal die kerk se leierskap 'n ondubbelsinnige en verantwoordelike standpunt daaroor moet inneem en dit in die kerk moet vestig.

Die uitvoerende beamptes van die kerk moet met 'n doelbewuste plan die motivering van voortgesette opleiding bestuur. Daar kan met die volgende begin word:

- Pastorale skrywes kan deurlopend aan pastors, gemeentes en streekrade gerig word waarin die belang van voortgesette opleiding beklemtoon word, en waarin hulle op hoogte gehou word van die beskikbaarheid van goeie en erkende voortgesette opleiding. Die navorsingsresultate van die deelnemers aan die kwalitatiewe ondersoek kan hier as uitgangspunt gebruik word. Op so 'n wyse kan die onbekendheid van formele tersiêre opleiding, en onkunde oor nuwe studierigtings, uit die weg geruim word.

- Dit is veral van kardinale belang dat die pastor op die etiese kwessie ten opsigte van die werwing van twyfelagtige kwalifikasies gewys word. Twyfelagtige kwalifikasies is niegeakkrediteerde kursusse en grade wat by niekredietwaardige instellings bekom word.

- Daar kan met verskillende kerke se leierskap in gesprek getree word oor wat voortgesette opleiding na hul mening behels. Nuwe, bruikbare idees kan daaruit voortspruit wat die proses om 'n nuwe kultuur onder pastors te skep ook kan bevorder.

- Die pastor se beeld kan uitgebou en bevorder word. Deurlopende navorsing oor doeltreffende rolfunksionering van die pastor moet deur die AGS se hoofkantoor beplan word. Só kan verdere riglyne ter ondersteuning van gehaltevoortgesette opleiding neergelê word. Beheer oor die verpligte evaluering van pastors moet as 'n prioriteit beskou word. Hier kom persoonlike evaluering ter sprake, waar die pastor se sterk punte en groei-areas bepaal word.

\section{Die AGS se teologiese instelling}

Die AGS se nuwe teologiese instelling is verantwoordlik vir:

- Seminare reël in samewerking met die AGS se hoofkantoor, plaaslike gemeentes, streekrade, pastors en gemeenskapsinstellings, waarin die AGS-pastor aan relevante gebiede in teologiese opleiding blootgestel word wat noodsaaklik is vir doeltreffende rolfunksionering.

- Alle inligting oor teologiese kursusse aan die AGShoofkantoor, plaaslike gemeentes, streekrade en pastors beskikbaar stel. 
- Pastors oortuig van die waarde van goeie, erkende opleiding, en hulle veral op die etiese kwessie ten opsigte van die werwing van twyfelagtige kwalifikasies, synde niegeakkrediteerde kursusse en grade by niekredietwaardige instansies, wys.

- Deurlopende ontmoetingsessies met die AGS-kerk se uitvoerende beamptes, streekraadleierskap, plaaslike gemeentes se bestuursrade sowel as pastors reël en beplan om voortgesette opleiding te bemark.

- Pastors wat reeds in die bediening staan en wat by voortgesette opleiding baat gevind het, gebruik om ander pastors te bemoedig en tot voortgesette opleiding te begelei

- $\quad$ kennis neem van, en aandag skenk aan, pastors en gemeentes se voorstelle en vrae oor voortgesette opleiding.

- Deur middel van e-pos en 'n webblad die nodige inligting oor voortgesette opleiding oordra.

- 'n Voortgesette-opleidingsprogram instel wat relevante gebiede vir doeltreffende rolfunksionering dek, en 'n puntestelsel aan kursusse koppel.

- Aan alle pastors studentenommers toeken, wat hulle dan toegang gee tot die seminarium se webbladsy om relevante inligting af te laai, wat insluit 'n webblad-afdeling met 'n puntetoekenningstelsel, waar pastors vir vordering beloon kan word deur sekere opdragte te voltooi.

- 'n Begroting vir 'n voortgesette-opleidingsprogram opstel en persone aanwys wat hulle met die bemarking en uitvoering van die program kan help, wat registrasie, debietorders, ensovoorts behels.

- Toesien dat' $n$ voortdurend bygewerkte databasis beskikbaar is, wat toegang bied tot leermateriaal, die jongste kursusse, en alle ander inligting oor teologiese opleiding.

- Relevante en eietydse leesstof aan pastors beskikbaar stel, waaroor die pastor 'n resensie moet skryf wat kwartaalliks gemoniteer word.

\section{Plaaslike gemeentes}

Die belangrike rol wat die plaaslike gemeente en werkgewer van die pastor moet vervul om in samewerking met die teologiese seminariums by voortgesette teologiese opleiding betrokke te raak, is reeds in die studie uitgewys.

Die volgende voorstelle is riglyne wat gemeentes kan help om op 'n meer indirekte wyse by pastors se voortgesette opleiding betrokke te raak:

- Die plaaslike gemeente moet oortuig wees van die voordele wat dit inhou as hul pastor aan voortgesette opleiding deelneem, sodat dit deel kan word van die vereistes wat aan pastors gestel word. Op dié wyse kan die gemeente sterker klem lê op die voordele van voortgesette opleiding, en minder daarop konsentreer om aanhoudend onrealistiese rolverwagtinge van pastors te koester.

- Die plaaslike gemeente moet vir voortgesette opleiding begroot. As aansporingsmaatreël vir die pastor, moet die puntestelsel waarvolgens opleidingsinstansies voltooide kursusse beloon, ook finansiële voordeel behels.

- Verantwoordelikheid moet aanvaar word vir deelname aan die emosioneel-geestelike versorging van die pastor.

- Gemeentes moet pastors aanmoedig om, ongeag hul ouderdom, by 'n mentorprogram van die teologiese seminarium en die AGS-hoofkantoor in te skakel. Die gemeentes moet ook vir die uitgawes van so 'n mentorprogram begroot.

- Die gemeente behoort saam met die AGS-hoofkantoor, teologiese instellings en streekrade toesig te hou oor die leer en lewenswandel van die pastor, wat as grondslag vir meriete- en aansporingsbonusse kan dien.

- Die pastor se teologiese akademiese vordering moet deurlopend geëvalueer en gemoniteer word.

- Hulp moet verleen word met die uitwys en bepaling van pastors se gawes en talente, wat dan deurlopend uitgebou en ontwikkel moet word.
- Finansiële bydraes moet aan die teologiese instellings gelewer word om die skep van materiaal en kursusse in die voortgesette-opleidingsprogram te bevorder en te ontwikkel.

- Daar moet deurlopend vir pastors gebid word en hulle moet voortdurend aangemoedig en gemotiveer word.

Die uiteindelike doel is dat die pastor so duidelik sal ontwikkel en vooruitgaan dat dit gemeentelede persoonlik sal aanspoor om ook voortdurend te groei.

\section{Streekrade}

Streekrade as middelvlakbestuur in die AGS het 'n kernrol te speel in die voortgesette teologiese opleidingsprogram vir pastors op hul gebied. Die volgende voorstelle is riglyne wat streekrade kan help om op 'n meer indirekte wyse daarby betrokke te raak:

- Die AGS-hoofkantoor en teologiese instellings moet streekrade deurlopend bewus maak van die belang om voortgesette opleiding onder AGS-pastors aan te moedig en nie net met sekere geestelike en administratiewe take besig te bly nie. Op dié wyse kan die enkele pastorsbidure wat pastors in geografiese streeksverband moet bywoon, en waar besprekingspunte oor die algemene gemeentebediening hanteer word, beter benut word om die AGS-pastor voldoende toe te rus.

- Streekrade moet voortgesette opleiding onder pastors aanmoedig deur motiverend, koördinerend en toesighoudend met teologiese seminariums saam te werk. Hulle kan dosente van die teologiese seminariums nooi om die belangrike saak van voortgesette opleiding te verduidelik.

- Streekrade moet spanverwante geleenthede onder pastors aanmoedig. Moontlikhede hier sluit in studiegroepe en ondersteuningstelsels.

- $\quad$ Streekrade moet vir voortgesette opleiding begroot, veral op gebiede waar pastors graag by opleiding betrokke wil raak, maar waar hul gemeentes nie finansieel daartoe kan bydra nie. Op dié wyse kan die probleem van moeilike ekonomiese omstandighede wat steeds teologiese opleiding rem, opgelos word.

\section{Pastors}

AGS-pastors is die kernfigure in teologiese opleiding. Dit is húlle wat die werksdruk ervaar; geldtekorte beleef; twyfel of voortgesette opleiding die moeite werd is, en uiteindelik die werk wat voortgesette studie verg, moet aanpak. Hulle moet oortuig word om aan voortgesette opleiding deel te neem. In hierdie verband moet die volgende aspekte aandag geniet:

- Pastors moet deurlopend van die noodsaaklikheid van voortgesette opleiding bewus gemaak word, sodat doeltreffende rolfunksionering te alle tye bewerkstellig kan word.

- Pastors moet vir hul eie opleiding verantwoordelikheid aanvaar en met die kerk saamwerk om dit te verwesenlik. Artikels deur pastors oor die persoonlike verryking wat hulle as gevolg van voortgesette opleiding ervaar het, kan in die amptelike kerkblad verskyn om ander pastors te motiveer.

- Pastors moet gemotiveer word om hulself in vele opsigte te ontwikkel, wat die volgende insluit:

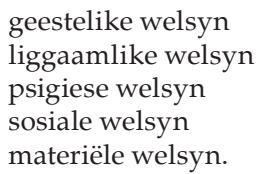

- Pastors moet gemotiveer word om in 'n mentorverhouding te staan met 'n dosent van 'n teologiese seminarium, of ' $\mathrm{n}$ kollega wat opleiding aanmoedig. 
- Daar kan van jong pastors vereis word om vir ten minste twee jaar saam te werk met 'n dosent van 'n teologiese instelling wat voortgesette opleiding aanmoedig.

Dit blyk duidelik dat die AGS-hoofkantoor, teologiese instellings, streekrade en plaaslike gemeentes spesifieke bydraes moet lewer om 'n nuwe kultuur onder pastors te vestig, sodat voortgesette opleiding ' $\mathrm{n}$ realiteit kan word. Dit is duidelik dat dit veel inspanning en geduld sal verg om die tradisionele pastor by voortgesette opleiding betrokke te kry. Indien dié proses egter oordeelkundig en aanloklik aangebied word, met onder meer rekenaar- en internetopleiding, 'n gimnasiumkaart, 'n merietebonus, en ander voordele daaraan gekoppel, kan dit die pastor dalk tot optrede aanvuur.

Indien die pastor in die loop van sy voortgesette opleiding besef dat hy besig is met iets wat nie alleen tot die uitbou van die koninkryk van God kan bydra nie, maar ook persoonlike verryking en vooruitgang meebring, sal hy voortgesette opleiding na waarde begin skat.

\section{Samevatting}

Indien pastors bewus gemaak word van al die jongste studierigtings wat verskeie universiteite en die Aucklandpark Teologiese Seminarium (ATS) aanbied, kan dit baie daartoe bydra om vooroordele wat hulle (dalk weens onkunde) jeens formele akademiese studie koester, uit die weg te ruim. Vele AGS-pastors wat by voortgesette teologiese studie betrokke geraak het, het ervaar dat hulle veel meer as net goeie begeleiding en ondersteuning ontvang het. Die kursusse wat verskeie universiteite beskikbaar stel, behels praktyk- én Bybelgerigte opleiding wat die pastor toerus en bekwaam maak om doeltreffend aan sy rolverwagtinge te voldoen. Statistieke oor honneurs-, magister- en doktorale studente bied 'n duidelike aanduiding dat universiteite 'n positiewe bydrae lewer om afstandsonderrig onder AGS-pastors 'n werklikheid te maak en om nuwe studierigtings te bevorder.

\section{OPMERKINGS OOR DIE 2006- EN 2009-ONDERSOEK}

\section{Riglyne vir toekomstige studie}

Putter (2006:81-146, 2009:1-7) se ondersoeke het 'n vernuwende bydrae tot die debat oor voortgesette teologiese opleiding gelewer, in besonder met betrekking tot die AGS-pastor. Dit is die eerste studie waarvoor die AGS-hoofkantoor 'n deel van die groter AGS-lidmaatskap as verteenwoordigers gekies, en 'n streekraad van die AGS (Ophir Netwerk) sy pastors aan 'n wetenskaplik getoetste navorsingsondersoek laat deelneem het. Die ondersoeke het tot 'n aantal belangrike temas en subtemas gelei, wat as riglyne kan dien vir toekomstige voortgesette teologiese opleiding vir die AGS-pastor. Die waarde van die Putter-ondersoeke ten spyt, bestaan daar dalk egter steeds sekere navorsingstekortkominge en -moontlikhede wat aandag verg voordat formele strukture gevestig kan word om pastors te begelei om by voortgesette opleiding betrokke te raak. Belangrike sake wat nog aandag verg, word hier onder uiteengesit.

- Deurlopende navorsing is nodig om vas te stel of die inhoud van voorgraadse en nagraadse teologiese opleiding tersaaklik is. Dít sou belangrik wees vir die nuwe teologiese instelling in die AGS wat nuut oor opleiding gaan besin. In aansluiting hierby kan kursusse van die destydse teologiese instellings van die AGS, én hul aanbiedingstyl, beoordeel word. Die AGS-hoofkantoor behoort dus 'n samewerkingsproses tussen al die teologiese rolspelers in die AGS te fasiliteer.

- Deurlopende navorsing behoort ook in die toekoms onder die lidmate en pastors van die AGS onderneem te word om vas te stel hoe hulle teologiese opleiding vir die AGS-pastor beleef. Hierdie navorsing behoort onder alle bevolkingsgroepe, in sowel stedelike as plattelandse gebiede, uitgevoer te word.
- Die Putter-navorsing was kwalitatief van aard. Dít skep die moontlikheid van verdere kwantitatiewe navorsing, waarin die resultate van die kwalitatiewe studie met behulp van vraelyste onder 'n groter groep AGS-pastors getoets kan word. Verdere kwantitatiewe ondersoeke kan help om voortgesette opleiding van pastors in die hand te werk, wat die doeltreffendste en mees tersaaklike rolfunksionering tot gevolg sal hê.

- Dit is veral van die allergrootste belang dat alle kerke en hul leiers sal toesien dat die verwerwing van twyfelagtige teologiese kwalifikasies ten sterkste afgekeur word. Indien die AGS-kerk hierin sou slaag, sal dit'n beduidende bydrae lewer om enersyds geloofwaardige voortgesette opleiding tot sy reg te laat kom, en andersyds te keer dat pastors by akademiese erkenning betrokke raak wat nie eties verantwoordbaar is nie.

\section{SLOT}

Wat duidelik uit die studie geblyk het, is dat die vestiging van 'n kultuur van voortgesette en doeltreffende opleiding 'n lang proses sal wees, wat nie alleen 'n spanpoging van die hele kerk sal verg nie, maar ook opofferings en voortdurende navorsing om voortgesette teologiese opleiding te bevorder. Die kerk moet in sy geheel deur teologiese opleiding gehelp word om sy mense beter te versorg en die kerk se sendingskarakter te bevorder.

Gespesialiseerde opleiding, en daarmee saam geestelike vorming, kan verlore gaan wanneer die AGS-hoofkantoor, plaaslike gemeentes en streekrade self pastors wil oplei, aangesien die gehalte van die opleiding daardeur verswak kan word en opleiding gevaar kan loop om net op die praktiese te fokus. Die oplossing is dat die kerk in sy geheel sal besef dat pastors nie sonder gespesialiseerde opleiding werklik doeltreffend kan funksioneer nie.

Die grootste uitdaging waarvoor pastors te staan kom, is om by voortgesette opleiding betrokke te raak, en nie toe te laat dat vrese en onsekerhede hulle daarvan weerhou nie. Die AGSkerk kan dan met groot opgewondenheid en entoesiasme na die toekoms van pastors uitsien, en die werk van die Here in dié kerk kan met rasse skrede vorder.

\section{LITERATUURVERWYSINGS}

AGS van SA, 1909, 'Notules: Blanke Uitvoerende Raad (NBUR)', AGS-argief, Johannesburg.

AGS van SA, 1932, 'Notules: Blanke Uitvoerende Raad (NBUR)', AGS-argief, Johannesburg.

AGS van SA, 1950, 'Notules: Blanke Uitvoerende Raad (NBUR)', AGS-argief, Johannesburg.

AGS van SA, 1957, 'Notules: Blanke Uitvoerende Raad (NBUR)', AGS-argief, Johannesburg.

AGS van SA, 1964a, 'Notules: Sendingkomitee (NSK)', AGSargief, Johannesburg.

AGS van SA, 1964b, 'Notules Swart Werkers Raad (NSWR)', Johannesburg

AGS van SA, 1969, 'Notules: Blanke Uitvoerende Raad (NBUR)', AGS-argief, Johannesburg.

AGS van SA, 1970, 'Notules: Kleurlingkuratorium (NKK.)', Sarepta Teologiese Kollege, Kuilsrivier.

AGS van SA, 2008, 'Algemene Besigheidsvergadering in die AGS', Johannesburg, 20-22 Mei.

Burger, I.S. vd M., 1987, Geskiedenis van die Apostoliese Geloof Sending van Suid-Afrika, Evangelie Uitgewers, Braamfontein.

Burger, I.S. vd M. \& Nel, M., 2008, The Fire Falls in Africa [Die Vuur val in Afrika], Christian Publishing Company (Cum Books), Vereeniging.

Burns, N. \& Grove, S.K., 1993, The practice of nursing: Conduct, critique and utilization [Die beoefening van verpleging: Gedrag, kritiek en aanwending], Saunders, Philadelphia. 
Codrington, G., 2004, Mind the gap [Oppas vir die gaping], Penguin Books, Johannesburg.

Creswell, J.W., 1994, Research design: qualitative and quantitative approaches [Navorsingontwerp: Kwalitatiewe en Kwantitatiewe benaderings], Sage, Thousand Oaks.

Cronjé, F.H.J., 1976, AGS Werkersraad verslagbundel, Die ATS Teologiese Kollege, Johannesburg.

Cronjé, F.H.I., 1979, AGS Werkersraad verslagbundel, Die ATS Teologiese Kollege, Johannesburg.

De Witt, P.J.H., 2010, Mondelinge mededeling aan AGShooftesourier, Centurion. (Kassetopname in besit van die outeur)

Easum, B., 2001, Unfreezing moves. Following Jesus into the mission field [Ontvriesde bewegings: Volg Jesus in die sendingveld], Abingdon Press, Nashville.

Erasmus, L.J., 1990, 'Uitbranding onder Apostoliese Geloof Sending pastors: 'n Prakties-teologiese ondersoek', MThproefskrif, Departement: Praktiese Teologie Universiteit van Suid-Afrika.

Erasmus, L.J., 1996, AFM unity in theological education? A historical perspective [AGS eenheid in teologiese opleiding? 'n Historiese perspektief], International Theological Institute, Midrand.

Evangelical Lutheran Church in America, 1995, 'Study of Theological Education: Faithful leaders for a changing world. Theological education for mission in the ELCA [Studie van Teologiese Opvoeding: Betroubare leiers vir ' $\mathrm{n}$ veranderende wêreld Teologiese opvoeding vir sending in die ELKA]', verslag aan die 1995 Wêreldwye Gemeente, Evangelical Lutheran Church in America, p. 12, Chicago.

Eybers, I.B., König, A. \& Stoop, J.A., 1978, Inleiding in die Teologie, NG Kerkboekhandel, Pretoria.

Grobbelaar, K.G., 2007, 'Hulpverlening tot streshantering by predikante van die Gereformeerde Kerke in Suid-Afrika (GKSA): 'n Pastorale studie', PhD-proefskrif, Departement Praktiese Teologie, Noordwes-Universiteit.

Hendriks, H.J., 2004, Studying Congregations in Africa [Bestudeer gemeentes in Afrika], Lux Verbi, Wellington.

Holliday, A., 2002, Doing and writing: qualitative research [Doen en skryf: Kwalitatiewe navorsingl, Sage, Thousand Oaks.

Joubert, S.J., 2001, 'Teologiekroniek: Die relevansie van teologie in millennium drie', Verbum et Ecclesia 22(1), 191-197.

Kimbal, D., 2003, The emerging church [Die ontluikende kerk], Zondervan, Grand Rapids.

Knafl, K. \& Breitmayer, B.J., 1989, 'Triangulation in qualitative research: Issues of conceptual clarity and purpose [Trangulasie in kwalitatiewe navorsing: Kwessies van konseptuele helderheid en doel]', in J. Morse (ed.), Qualitative nursing research: A contemporary dialogue, pp. 193-203, Aspen, Rockville, Maryland.
Krefting, L., 1991, 'Rigour in qualitative research: The assessment of trustworthiness [Die nougesetheid in kwalitatiewe navorsing: Die waardebepaling van betroubaarheidl', American Journal of Occupational Therapy 45(3), 214-222.

Maré, L.P., 2003, 'AGS-pastors se belewenis van hulle teologiese opleiding', MA-proefskrif, Departement Teologie, Randse Afrikaanse Universiteit.

Maré, L.P., 2005, 'AGS pastors se belewenis van hulle teologiese opleiding', In die Skriflig 26(2), 432-446.

Nel, M., 2002, 'Predikante opleiding: Roeping, keuring en legimentering', Verbum et Ecclesia 23(1), 151-167.

Nel, M., 2005, 'Public pastors leaders: The purpose of thoelogical training [Die doel van teologiese opleiding]', In die Skriflig 39(3), 441-462.

Olwagen, J.M., 2003, 'Die paradigmaskuif wat'n tradisionele AGS pastor moet ondergaan vir effektiewe gemeentemobilisasie', MA-proefskrif, Departement Teologie, Randse Afrikaanse Universiteit.

Putter, A.P. J., 2003, 'Die mobilisering van lidmate in 'n tipiese AGS gemeente Robertsham', MA-proefskrif, Departement Teologie, Randse Afrikaanse Universiteit, Johannesburg.

Putter, A.P., 2006, 'Die voortgesette akademiese ontwikkeling van die AGS-pastor', PhD-proefskrif, Departement: Geesteswetenskappe, Universiteit van Johannesburg.

Putter, A.P., 2009, Die Ophir Netwerk-pastor se onderskeie rolverwagtinge: Uitslae van die eksterne kodeerder, Universiteit van Limpopo, Medunsa-kampus.

Sweet, L., 1999, Soul Tsunami [Siel Tsunami], Zondervan Publishing House, Michigan.

Terreblanche, S., 2002, A history of inequality in South Africa: 1652-2002 ['n Geskiedenis van ongelykheid in Suid-Afrika], University of Natal, Pietermaritzburg.

Thompson, L., 1990, A history of South Africa ['n Geskiedenis van Suid-Afrika], Yale University Press, London \& New Haven.

Van den Berg, J.C., 1991, 'Die pastor en lidmaat in die Apostoliese Geloof Sending van Suid-Afrika: strukturele fasette en bedieningsmodelle', MTh-verhandeling, Departement Praktiese Teologie, Universiteit van Suid-Afrika.

Van der Spuy, M.A., 1985, 'Die spanning tussen vryheid en formalisering ten opsigte van die liturgiese verskuiwings binne die Apostoliese Geloof Sending van Suid-Afrika', MTh-verhandeling, Departement: Praktiese Teologie, Universiteit van Suid-Afrika.

Van Niekerk, A.S., 2000, 'Die gesamentlike teologiese oplossing: 'n Wonderwerk wat moet werk', Nederduits Gereformeerde Teologiese Tydskrif 41(3-4), 350-365.

Zwemstra, H.M., 2007, 'Die roeping van die kerk ten opsigte van sosio-ekonomiese regte in Suid-Afrika: 'n TeologiesEtiese studie', ThD-proefskrif, Departement Dogmatiek, Potchefstroomse Universiteit vir Christelike Hoër Onderwys (nou Noordwes-Universiteit). 